\title{
TYPES OF CHILDREN POEM IN DIVAN AL-ATFAL BY SULAIMAN AL-ISA
}

\author{
Akram Roshanfekr [1], Sadegh Askari [2], Somayeh Akbarpour [2][3]
}

[1] saneh210@yahoo.com, [2] s.askari2011@gmail.com, [3] akbarpour_somayeh@yahoo.com

[1] University of Guilan, Rasht, Iran

[2] University of Semnan, Semnan, Iran

\begin{abstract}
Children poem is a literary type which has the potential to be versified with other different types. Children poet is aware of child's interests and mood. Sometimes by using easy words and fluent phrases and proportionate to the notion, it tries to help the child in learning and expanding his vocabulary domain with new words. In this way, poem verses are versified with the aim of teaching notions and categorized under didactic poetry type. Sulaiman al-Issa from Syria is considered among the founders of children poem in Arabic literature. He has a Divan entitled 'Divan al-Atfal'. The present study with a descriptive-analytic approach attempts to review it with the aim of determining the typology of his poems. The most important result of the article is the presence of nature poem, didactic poem, as well as social and entertainment poetry types in Divan al-Atfal.
\end{abstract}

Keywords: Children Poetry, Nature Poem, Sulaiman al-Issa, Divan al-Atfal

\section{INTRODUCTION}

Children and teenagers' literature is marked by age, far from maturity or near it and includes those works which are written according to need, interest, ability, and the motivation of child and teenager. Although not composed for the sake of direct education and in the format of curriculum, some goals could be associated with these works. They are appropriate with the limited experience, vocabulary bank, accuracy time, and little power of child and teenager for understanding different events determined in a certain time.

Those works are created for children and teenagers' usage form different shapes such as poetry, story, play, film, animation, and so on. However, it seems that children and teenagers' poetry is the most prominent literary form for toddlers. The background of these poems in different nations' literature traces back to old ages. In addition, their present form is the result of civil development and different intentions that the poets of this type in nations' literature consider for their compositions.
Sulaiman al-Issa (1921-2013), Syrian poet and laureate, known as children poet was born in a village close to Antioch. He has left some poem collection and many literary researches behind. His poems and songs mostly have epic music. He is mainly famous for composing children poetry. al-Issa is considered among the founders of children poetry in Arabic literature, and some have called him the king of children poets. He has poem Divan called 'Divan al-Atfal' which has many fans in Syria and other Arabic countries. After 1967 (coincided with the third war of Zionist regime with Arabs) he started writing children poetry. In addition to that he had significant role in translating world different nations' stories and plays. Sulaiman al-Issa was chosen as the member of Arabic language convention in Damascus in 1990 and also received the poetic innovation from Albabetin institute in 2000. His most important works in children poetry include 'Aghniyeh fi Jazireh alSandbaz', 'Divan al-Atfal', 'Sher al-Atfal', and 'MasrahiyeShe'ruy le-Atfal'.

Thus, the present research starts with a question based on the manner of poet's usage 
of different types of children poem in expressing themes, by descriptive-analytic approach studies 'Divan al-Atfal' by Sulaiman al-Issa. About the research background, works such as 'Sulaiman al-Issa: Eighty Years Dream and Wish' by Ibrahim al-Jaradi, 'Some Pauses with Sulaiman al-Issa' by MalakehAbiz, 'With Sulaiman al-Issa' which some of writers have written could be mentioned. The article 'The Presence of Algeria Revolution in Syrian Poetry: The Case Study of Sulaiman al-Issa Poetry' by ImanFatemeh al-Zahra Belghasem could be mentioned that its writer has spoken about Syrian poetry's approach toward Algerian revolution and Sulaiman al-Issa's poems. However, the present study is the first typological survey in 'Divan al-Atfal' by Sulaiman al-Issa.

\section{CHILDREN LITERATURE FOR ARAB NATIONS}

Children literature in poem and story form is considered a part of Arabic culture. Yet, for long years it was ignored from production quality and criticism until powerful laureates and critics of Arab world such as Ahmed Zelt, Abdoltavab Yousef, Abdollah Abouheif, Mohammad Gharania, and Abdolaziz Al-meghlahin recent decades have studied this literary form (Nezamdoust, 2011, p. 6).

In this regard, al-Meghlah does not consider the present children literature for the realization of Arab child's ambitions and his needs as enough. Futhermore, he viewed Ahmed Shoughi, Kamel al-Kilani, Abdoltavab Yousef, and even Sulaiman al-Issa's efforts in comparison to new demands as inadequate. Therefore, some of Arab descended researchers and laureates believe that the empty place for children literature especially children poem is felt (Alheiti, 1977, p. 214).

It is worthy of attention that the third war of Zionist troops with Arabs in June 1967 had a deep influence on Arab descended people's life. Some of the thinkers of society considered making the new generation and children, who are the building blocks of future, as the way for release from the bitter consequences of that war. They tried to concentrate their efforts on restoring society's thoughts through writing for the kids. For this reason, Zakaria Tamer and Sulaiman al-Issa put their attention to children story and poetry (Ahmed, 1985, p. 13).

Then, 'Commitment to National-Ethnic Culture of Arab Children' conference was held in 1970 in Beirut by Secretariat of the Arab League invitation. Additionally, the third subject of tenth conference of Arab literature (Algeria - 1975) was also 'Child in Arab Literature' which Syrian laureates tried more than other nations in that. Sulaiman al-Issa published three magazines including story, song, and play for schools (Zanghaneh, Adabestan Magazine, p. 15). Literature tendency to children literature until the half of the $20^{\text {th }}$ century was educational, and children books were limited to those goals and subjects (Zelt, 1994, p. 26). As al-Issa (Al-Issa, 1979, GhanouYaAtfal Introduction) in 'GhanouYaAtfal' Divan starts complaining and says:

Our literature is deprived of children poetry. I have said several times that our poets are embarrassed of writing poem for children and creating smile on their lips. Our children are deprived of smile, beautiful songs, and true poetry. Our literature has a widespread history, but it is deprived of children poetry. May God bless our master Ahmed Shoughi who had felt this matter before and has opened the way for us.

In this way, children poetry in Syria surpassed their story, and newspapers and magazines specially edited for children were published (al-Mosa, 2010, p. 74).

\section{CHILDREN POETRY FOR SULAIMANAL-ISSA}

al-Issa considers children poetry as a kind of equation (Yousef, 1970, p. 30) and in its definition says:

The true poetry is the easy hard poetry, close far. It is easy because children read it and soon memorize it. It is hard because some of its meanings and forms are complicated and far from toddlers' understanding. The ease in children poetry is intentional and is called beautiful poetic equation; this equation requires much effort so that each song and verse is versified to the best of one's ability.

al-Issa(1999, p. 30) says:

I don't write for children to console them. Maybe childish game is more 
beneficial. 0 my dear children! I transferred my ethnic-national experience, human and technical experience, and sorrows and wishes to you .... When you grow up a little more, you'll see that I haven't lied to you and haven't wasted your precious time with nothing. You are precious to me and are the dearest for me. You are worthy to carry this great trust, the trust which would return the great Arab nation, which would take them back to humanity so that they would participate in creativity once more.

\section{POETIC TYPES IN 'DIVAN AL-ATFAL' ACCORDING TO DIVERSITY OF THEMES}

The definition of type in literature is done through knowing literary genres. The main subject of literary typology is the classification of works based on matter and form in limited and distinguished groups (Shamisa, 1999, p. 13). The types of al-Issa's poem according to matter and content are different. He has made educative advice, educational goals, and national motivations of natural phenomena and its beauties and has utilized entertainment and emotion and pluralism to reach to his intended themes.

\section{Nature Poetry in 'Divan al-Atfal'}

Nature makes the child watch through its phenomena. He captures in mind the realities including things that he has seen and knows, and heard and recognizes, and the poet can create new images by using description technique and considering the low ability of child along with abundant joy (Boulhassani, 2006, p. 96).

Natural phenomena with vastness and variety, and beauty and pleasantness have wondrous proportion with child's desire and his mental-psychological characteristics. Piaget believes that the boundary between living and inanimate is hidden for the children and they base everything on being alive and attribute life and its complications to all things and the phenomena around them (Balali, 2000, p. 12).

Nature poetry not only describes natural phenomena and delineates colors and the different forms of those phenomena but also having an elegant style and selected words pictures them the way they are (al-
Tounji, 1993, Volume II, p. 559). This type of poetry has the most usage in Sulaiman alIssa's 'Divan al-Atfal', and he talks for children about natural phenomena such as the following.

\section{Seasons}

Spring has various colors, happiness, and freshness for al-Issa, and it is the season of new revival of nature. Yet, he has avoided repetition and stereotypical speech and has used spring for expressing concepts such as hope, happiness, and smile. In his poems, alIssa pictures children along with flowers and tries to stimulate their feelings toward beauty and art and draw their attention to nature and change of season and weather. The poet considers summer as the season of children's smile and introduces it as the season of school's end and game and happiness and harvesting. Autumn has two completely different faces in poets' poems; sometimes happy and joyous and sometimes sad and depressing. Even when Sulaiman al-Issa's poems delineate autumn as depressing and shedding leaves season it immediately brings hope and smile on children's lips and makes them happy with news of going to school and happy news. Autumn, in his poems, indicates happiness, and it is connected with beginning of the school year. He describes children along with the beautiful nature of autumn and in winter invites children to sit beside fire and speaks of fierce and cold winds of winter and sparrows which escape from the cold. Therefore, in the poem 'The Songs of Four Seasons', al-Issa (1999, p. 622) remembers four seasons and their pleasing features:

Spring; the season of rains and blooms/It is the season of long green shadows/ Summer; the season of journeys and harvesting grains/ The season of very generous gardens/ Autumn; the season of shedding leaves/ Season of rainy clouds/ Season of blasting fast winds/ Winter; 0 the fire of night gatherings/ 0 grandmas stories/ Water freezes in you.

$\mathrm{He}$, then in separated songs, describes nature in spring, summer, autumn, and winter and pictures the face of life in them. As in the poem 'Spring' he sends sheep to spring meadows and pastures and mixes the sound of swallowing fresh grass with the ongoing 
gurgle of valley river and in 'Summer Speaks with Children' personifies summer. Accordingly, by using personification technique he makes coquetry in starry and moonlit night and speaks of golden fields, ripe fruits, and happy holiday. He in the poem 'Autumn' with scattering leaves in ways and delineating cloud masses and pouring rain talks about jumping of students and their happy songs on the way to school. In the poem 'Winter' sends winds embraced by rain to tree branches and raises stove fires and sends the child to the help of a sparrow which has taken refugee from cold. And in poem 'Snow' deals with describing white and lovely snow which is the free means for child's play in homes and streets and addressing in a childish manner: "O sparrow's white feather/ O snowflakes/ Cover our garden's trees/ On the pastures/ 0 sparrow's white feather/ O sound of guitar/ Sing a song on the balcony/ Cover the roof/ 0 snowflakes fall/ Cover the roads/ I will write my practice now/ And go for play" (al-Issa, 1999, p. 144).

\section{Animals}

Sulaiman al-Issa, in his poems, pays attention to different types of nature animals. It includes rodents like rat and rabbit, birds like sparrow and nightingale, duck and goose, crow and swallow, stork and partridge. Sometimes his theme becomes livestock and quadruped and semi-domesticated animal including sheep, cow, horse, dog, cat, and gazelle. Even he speaks of fox, wolf, and viper and by inviting the child to the zoo names leopard, giraffe, and cheetah and describes them. He sometimes speaks their language and sometimes by mentioning their onomatopoeia words describes them, and in this way he has provided some poems to benefit from the simplicity of children's relation with these dumb things and nurture their talent. Therefore, in the poem 'Kowkab, Noble Horse' from the viewpoint of a child who celebrated his birthday, he (al-Issa, 1999, p. 697) says:

I'm a rider/ I've a black and white horse/ I speak to him and Kowkab understands/ That's his name, I took it from the sky/ My horse is like a sharpened arrow, he's never exhausted/ One day Mos'ab rode it/ My friend Mo'sab, he did wrong/ With whiplash he started to make him haste/ My friend! Kowkab isn't whipped/My horse will take you anywhere you want with a whisper.

In 'Duck Song', the poet loans a language to duck to express a scene of their crowd's playfulness and by applying a proverb adds to the aural information storage of the child and says: "We are created with water/ We are born on water/ From old times they say the proverb about us:/ The ducking is the swimmer ...." (al-Issa, 1999, p. 668).

al-Issa sometimes by using the charm of storytelling creates a hero and sends a bee for saving a sheep from wolf's trap and by the detailed description of the adventure from toddler audience expresses his intention of storytelling. In 'Bee My Friend', al-Issa (1999, p. 337) says:

My grandma has told me/ By the soiree stove/ That a cranky wolf/ with teeth like dagger/ And eyes full of evil/ Came one dawn/ After a lost sheep/ He saw it asleep by tree's shadow/... he prepared to jump on his prey/ A bee heard his sound/ He woke his friends up in a twilight weather/ In the blink of an eye, a convoy fell down/ And gathered the hunter with hundreds of needles (sting) ...

One time al-Issa also by help of his story's hero mixes a proverb with it, first narrates a story in poetic language and then mentions a proverb proportionate to it to put a luggage of his people's culture in toddler's kitbag. As in the poem 'Owl and Nightingales', he talks of some nightingales that were singing on garden branches until an owl comes to their visit and introduces himself as songwriting teacher. He fills garden's atmosphere with his wicked sound and scatters passenger's convoy who were seeking relief under the shadow of that garden. Subsequently, the poet ends his story with a proverb and says: "Many times a caw silences a beautiful sound, and many times the wicked sound of crow take the room from nightingale's sound" (al-Issa, 1999, p. 478).

\section{Colors}

One of the most admiring natural phenomena which has different colors in itself and is the theme of al-Issa's poem is the 
rainbow which the poet has chosen as the title of his poem and in 'The Rainbow' he explains each of its colors. He first draws the attention of the toddler to the blue sky and then chooses green land as the landscape of his poem. It then happily leads to the colorful bow of the sky that although it is colorful it suggests a unity which is the preserver of its existence. Then, the poet talks of the red blood of martyrs and the brunette country children and the magnificent blue of the sky. He also calls the yellowish sands of deserts of some parts of Arab descended realm "Kohl Rubbing of Ancestors' Eyes" to draw the attention of the toddler to the sublime concept of unity and integration of Arabic realm. Thus, he says: "Unity and integration is the asset of free men/ Which challenges every wall/ With thousands who will come tomorrow/ And thousands smile of tomorrow day" (al-Issa, 1999, p. 271).

al-Issa in the poem 'Crayons' also talks of colors, but his selected color which also draws the attention of the toddler the most is red. Therefore, with a childish language talks of the crayon box of a child which draws a red rose with red pencil and (al-Issa, 1999, p. 398) says:

I have a crayon box/ Pencils for drawing/ I draw a red rose like a star/ My mother said: You're that red rose/ My name is Da'd and my brother is Sa'd/ I sacrifice for my country that is magnificent/ I have a crayon box/ Like great artists.

\section{DIDACTIC POETRY IN 'DIVAN AL-ATFAL'}

Although the poem, that puts educational concepts as its goal, is categorized under classical methods of education in order to give data to the learner through poetic speech method, sometimes this method is also applied in informal and unofficial teachings. Therefore, some of the poems of Divan al-Atfal categorize under educational type, and al-Issa with these poems help child's learning with poetic repetition. In 'Beautiful Letters', the poet has versified alef (a) till ya (z) and had mentioned 28 letters of Arabic along with examples and in 'Light Song' draws the attention of child to school and teacher and learning Arabic language. Then in 'The Sweetest Language' admires his language and calls for its learning and says: "This is my class and these are my books/ Arab Sun shines in it/ My teacher! Welcome, welcome/ Hurry, let's read the sweetest language/ ... 0 the future waterfall, my language is the beat of life like you" (al-Issa, 1999, p. 222).

Of course, al-Issa is not satisfied with these references, and in the poem 'I will be a Flower Branch' he has placed himself in place of a child who learns cleaning from nature's purity and shows suitable behavior by waking up as he (al-Issa, 1999, p. 643) says:

Why not washing hand and face?/ Why not appear clear and clean?/ Don't flowers wash their bodies with rain drops?/ ... Ask red rose/ Does it become attractive without dew drops?/ I will be flower too, look at me/ When I clean my hand and face.

In each line of this poem, he has maintained a balance with other line, and by referring to the clean phenomena in nature he reaches to the cleanness and observing hygiene subject. He considers the rain as the factor for washing petals and recognizes the clean leaves of trees as the cause of refreshing space and sun shining. Then, he takes a handful of water from sea's wave to wash the face of beach's sand with it and in this way reveals a combination of wave's game with beach in cleanness. Then, poet's mastery is highlighted in dew drops which he puts at dawn on the face of petals. This way creates a pleasant harmony between flower's freshness and child's face and talks about child's washing hand and face in the morning to make a daily behavior pleasant for the kid.

Of course, al-Issa is not satisfied with teaching alphabet and individual hygiene. Nevertheless, in the poem 'Children of the Week' makes the song of week days and adorns everyday with a description to remain in child's memory, although weekend is so admirable for both; poet and the child. Therefore, he (al-Issa, 1999, p. 691) says: "Wow! How dear and pleasant is Friday!"

He who has highlighted his intention on teaching order by constant referring to week days, in 'My Small Library' sings the discipline song from the tongue of a child who arranges his books in the cabinet and considers them as his close friends and bright treasure. Then, in 'Little Reader' he reveals his intention and encourages the child to reading and says: "My name is Kamel/ My father is a worker/ I read 
the writings/ I read stories easily/ Lemon blooms/ Olive seeds/ Farmer's plow ..." (alIssa, 1999, p. 280). Encouraging reading is not the last goal of the poet, because in 'Little Writer' he considers the ability to write as the important goal of his young audience and narrates a story by dramatic dialogue. Therefore, al-Issa (1999, p. 282) says: "Kids: Bassam what are you writing?/Bassam, pen in his hand raises his head a little/ I write a story/ I make a story ...."

\section{SOCIAL POEM IN 'DIVAN AL-ATFAL'}

By social poems, it is meant that those poems which deal with social relations of the child in family environment and society outside the family or with a certain social class, and social problems and issues are placed in their center. In these poems, the role of social interactions is concerned not its educational role. The poet's goal is to emphasize on familial relations and its role in forming child's personality. Social themes are related to society and child relations in the society, which include respecting the elderly, valuing goodness, and other social concepts. In social themes, child's interaction with parents is concerned. Therefore, in 'Divan alAtfal' al-Issa has versified some poems with family approach, and he talks about them accordingly.

\section{Paying Attention to Family}

Child's feeling for parents especially mother is undeniable, and her presence has a direct influence on child's growth, as the interest in other family members and school teacher and friends also have significant effect on child's behavior. In the introduction of 'Divan al-Atfal', Sulaiman al-Issa says: "Children love language, country, people, flower, spring, and life, they learn sweet songs, and write a beautiful poem, a true poem for them" (al-Issa, 1999, p. 10).

This pause of the poet might be because of paying attention to children's emotions. Since emotions are actions and reactions which emerge according to individual's relation with others, things, and other beings, the first affectionate person for the child is the mother. She is his shelter and a realm that provides his security and comfort. She is the first instructor of the child and haven of tenderness and full of mercy. Those poems which deal with mother mostly delineate a human picture that its significant feature is kindness and devotion. Mother is at the beginning of those subjects which came in children poem (Al-Safdi, www.Thawra.Alwehda.Gov.sy).

He considers mother's place as sublime and places her in the hearts of her children. Mother is the secret of child's creation, and it's the haven of his bliss and happiness. Therefore, the poet has composed a song entitled 'Mother Song' and considers her as an eternal song and permanent light: "Mother! Mother! O sweet song/ You feel my heart with love voice/ You're my song, your feast is my feast/ My mother's smile is the secret of my existence" (al-Issa, 1999, p. 43).

Then, al-Issa considers the relations of family children with each other and in the song 'Brother' he pictures the beauty of brotherhood and feeling of innocence that brings the happiness of home: "I find no more beautiful word than brother/ When I say brother! The home is filled with light/ We are one light in eyes/ We are one voice in two lips" (al-Issa, 1999, p. 654).

Then, considering the gathered family the poet understands its meaning and places the smallest social institution as the aim of his poem, and in the song 'Family Try' refers to the group effort of family members and (alIssa, 1999, p. 505) says:

Where does laziness come from?/ Our home is a beehive/ Our home is work and effort/ Where does laziness come from?/ My mother wakes up with dawn dew/ She flourishes life in the home/ And my father is a serious activist/ He goes to work and comes back.

The poet has composed this poem using important values of child's life and using the singing of a brother and sister who repeat his poem; he gets to the theme of social effort. He has another poem entitled 'A House by the River Bank' sung by a little girl, and in this way she refers to describing their shelter and family's effort which light of hope has made bright and says: "We made it by the river/ Close to water and grass/ We made a magic house/ The scenes ... All magical/ All family is busy/ We cooperate with each other" (al-Issa, 1999, p. 494).

It seems that work is most precious social, educational, and moral value in al-Issa's 
'Divan al-Atfal'. Therefore, the poet draws the attention of the kids to that and highlights the role of participation. As the words 'family, cooperation, and work' in the mentioned poem suggest that. In 'Workers' Song', he also creates a sweet song through workers' words: "We make miracles by our hands/ We build up beautiful and persistent structures/ We build up thousands of columns and we build dams/ On the great Nile, on Forat waters/ Our land is full of powerful and devoted men" (al-Issa, 1999, p. 187). He introduces work and worker in this poem. By using words such as 'miracle, column, and dam' and mentioning their meanings in footnotes of every page, he pays attention to increasing the extent of child's vocabulary domain and introduces the jobs.

\section{Patriotism}

Sulaiman al-Issa is a poet who has dealt with national and patriotic values in his poem. Benefitted from Arabic nationalism and poetic emotion, he pays attention to unity problem and as it was previously mentioned in rainbow poem that its different colors stay together and form its existence is considered the secret of being together. Hence, in 'Children's Country', he uses clear and transparent words and by putting together 'justice, country, and treasure' words helps the child in understanding to value his soil and says:

What is enough for us, is in our hands/ Distribute your kindness and forgiveness justly among us/ Hurry! 0 the land of future/ Deal with whom that does not try/ ... Open up your chest for posterity/ The victory children come/ The sparrow told us/ All light treasures are in children realm (al-Issa, 1999, p. 86).

In 'Open up 0 Homeland', he considers his homeland as the land of kindness which springs with natural gifts and is the guiding star in all darkness (al-Issa, 1999, p. 723). In this way, fatherland enjoys the prime value in poet's word and becomes the axis of interaction and the base of social subjects of 'Divan al-Atfal'. Accordingly he makes the Palestinian child to speak up to narrate the painful matter of his land's invasion in 'Palestine is My Home':

Palestine is my home and my victory highway/ My land is a love in my heart/
It is a proud voice on my lips/ There are unfamiliar faces in my occupied land/ They sell my fruit and invade my home/ I know my highway and my nation will return/ To the paternal home, to the guided shelter/ Palestine is my home and my victory highway (al-Issa, 1999, p. 48).

Then in 'A Child from Palestine', al-Issa makes a child from Safad city to speak up, to explain the disasters which he has endured because of his land's occupation:

I'm from Safad/ They stole my country/ My occupied land, Palestine/ Lemon tree didn't bloom there/ Meadow didn't smile/ When yellow wind blew/ The land made flowers the pasture of death and fire/ Strangers came with rancor/ From all over the world/ With oppressors' bayonets/ A stranger took my father's home/ I was displaced a dark night/ I was exiled from my valuable home/ I don't remember how we were displaced/ Masses and masses of kids/ I from Yafa, I from Safad/ I didn't harm anybody/ Woe to thieves of my home/ Fire stands against fire/ I from Yafa, I from Safad/ My country! I make you free with my hands (al-Issa, 1999, p. 126).

The words of this poem are easy. By using 'Occupied land, not blooming, not smiling, death, fire, stranger, rancor, bayonet, dark night, displacement, robbery', it creates a disastrous atmosphere to express the detailed report of damages which were caused by Palestine occupation to the kids. Yet he bonds his promised hope, which is a feature of kids' poem, in the last words of Palestinian kid and speaks of country's liberation by the hands of children from Yafa, Safad, and so on. He also considers the solution in losing head for the country and in 'The Song of Martyr's Kid' remembers the prosperity of his homeland which would be fulfilled by children's will to continuing their martyred father's way. Therefore, he says:

Until you flourish my land!/ And Arabic flag blew/ On the land which is the carpet for widespread aspirations and the cradle of a prophet has been there/ We were wave of fury so the smile would not become pale/ We fought and my father died under the flag of 
martyrs/ I'm the son of eagle which spread its wings for your support/ I'm the son of eagle that its wings covers me and farewelled/ I'll fly, fly/ To surpass the convoy of time/ I'm the voice of martyr and his green fire 0 my land!/ Until hills and downhills and beaches became green/ Until man lives humane around you/ Until colorful children smell kindness/ ... (al-Issa, 1999, p. 193).

Although this poem is by the child of a person who was slithered in his own blood, words such as 'flourish, smiles, son of eagle, flying, human, children, and kindness colorful' maintain a suitable harmony with the promised optimism in children poetry. They have placed in over hopefulness and bright future and full of humanity.

\section{ENTERTAINMENT IN 'DIVAN AL-ATFAL'}

Entertaining and joyous themes are less noticed in poetry, but some of children literature researchers consider entertaining and joyous type as an independent type and have mentioned it as leisure literature. If this type of literature does have a message, mostly it is simple and without complication. "It is general atmosphere that is so bright that either happiness dominates all over it or it is ended with happiness" (Tahouri, 2002, p. 187). Some people also recognize childish world as a happy and noisy world that direct education will make it tedious and boring and the playful nature of the child will also refuse it. Therefore, they consider mixing the contents flavored with joy, laughter, and play as the best way for teaching contents to child (Taghipour, 2011, p. 4).

One of the themes which are placed under the entertainment poetry set include riddle-like poems and painting, poems of childish plays, poems including childish wishes, and poems with concepts of childish imagination. Proposing riddle in poem is one of the entertaining themes and its complication and the child's mental effort for finding an answer brings about a kind of joy. Childish plays are also versified in other poems in this way, because play has a vital role for the child as far as that childhood identity is basically integrated with the play. Children also speak up their imaginations during the play and it could be said that they think loudly. Informing this children's characteristic in 'Little Nabil Loves Playing' alIssa says about kid's unhappiness:

My mommy impedes me/ My daddy impedes me/ My older sister/ My older brother also/ That I play, that I run/ Like a rabbit in green field/ To dip my foot in the mud/ To come close to flower hills/ To take a handful of mud/ To return, while I have messed up my feet and my clothes with all the dirt of the neighborhood/ I'm a kid, I like playing/ I find pain sweet in that ... (al-Issa, 1999, p. 516).

If we are to introduce two important childish activities, certainly one of them would be play and the other one painting. Children's painting shows their inner world and it is a favorite activity of the child which entertains him. Also, in 'Little Painter' al-Issa pays attention to this matter and while quoting a child who considers himself an artist, says:

I paint mother and father with colors/ My flag over the peaks/ I'm an artist/ I'm the hunter of magical color/ My country's land is the treasure of scenes/ Let me paint the light of star/ The color of vine/ I write a poem with colors/ I live freely, I'm an artist (al-Issa, 1999, p. 130 ).

Of course, the child will be delighted not only by painting tools but also every tool that can entertain him. Therefore, the poet in 'Sa'd Flageolet' speaks of a child who sings some songs with flageolet sound for his friends in his birthday:

Sa'd's flageoletintrigues/ It is made by him/ If you hear his sound, the world will become pleasant/ Sa'd's flageolet is an angel which does coquetry with sweet singing/ He has named in freedom sound/ And dedicates it to his friend, Ra'fe' / Sa'd's flageolet is made of reed/ And has some holes which flow sounds/ Sa'd forgets exhaustion in them/ And a sparrow gets intoxicated/ Children of neighborhood meet each other/ And Sa'd plays some songs/ As if the world is a guitar which beats with Arabian lips (al-Issa, 1999, p. 219).

\section{CONCLUSION}

Children poetry has been noticed by great poets in Arabic literature like Sulaiman 
al-Issa. He has dedicated five of his works to children literature. Studying Divan al-Atfal of the poet has created the following results in the typology of his poem. The poet by pausing on the successful relation of the child with nature has dedicated some of his poems to describing natural phenomena and has paid attention to seasons, animals, and colors. alIssa has regarded child's learning in some poems and has versified some songs in order to teach concepts. He also has created some sort of didactic poem in poems like Horofana al-Jamile, Nashid al-Nour, AhliLoghat, SoufAbdoVerdeh, Atfal al-Sabou', Maktabati alAaghireh, al-Ghari al-Saghir, and al-Kateb alSaghir. Since literature raises from the context of its society and has a close relationship with its society, al-Issa by considering family as the smallest social institution has versified some poems. He creates a type of social poem in Divan al-Atfal which has led to the concepts of country and family. The poet in expressing the value of patriotism has used clear and transparent words and sometimes has stepped over his country's borders to get to the events of the occupied Arabian country and express the sufferings of Palestinian children. The entertainment poetry under leisure literature which has themes like riddle, painting, and childish plays has dedicated some of the poems of al-Issa in Divan al-Atfal to itself. Furthermore, the poet informed by child's interest to play and entertainment has dedicated some of Divan al-Atfal poems' to them.

\section{REFERENCE}

Azra, A. (2000). The Islamic factor in post-Soeharto Indonesia. In C. Manning \& P. V. Diermen (Eds.), Indonesia in transition: Social aspects of reformasi and crisis (pp. 309-318). Singapore: Institute of Southeast Asian Studies.

Ahmed, N. Y. (1985). al-Adab al-Ghosasi Le-Atfal-al-Ghosas al-Felestini al-Maktob Le-Atfal. Egypt: alDar al-Jamahirieyh Le-nashrva al-Tozi' va al-A'lan. (Narrative Literature of ChildrenPalestinian Stories Written for the Children).

Alheiti, H. N. (1977). Adab al-AtfalFalsafateh, Fononeh, vaVasaeteh(1 ${ }^{\text {st }}$ ed.). Cairo: Al-Hei'at Almesriyh Al-a'me Le-ketab. (Children's Literature, Its Philosophy, Techniques, and Its Requirements).

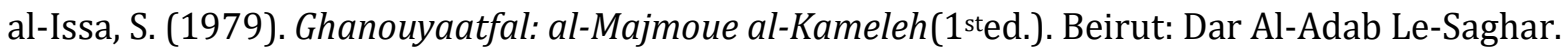

al-Issa, S. (1999). Divan al-Atfal(1'sted.). Damascus: Dar Al-fekr Mo'aser.

al-Mosa, A. A.. (2010). Adab al-Atfal Fan al-Mostaghbel. Beirut: Dar Al-Nehzat Al-Arabiyeh.

Al-Safdi, www.Thawra.Alwehda.Gov.sy

al-Tounji, M. (1993). al-Mo'jam al-Mofassal fi al-Adab(1 ${ }^{\text {st }}$ ed.). Beirut: Dar al-Kotob al-Elmiye.

Balali, R. (2000). Interview with Ja'farGhorbani. Book of the Month for Children and Adolescents, 11, 12-14.

Boulhassani, N. (2006). Children and youth's literature. Tehran: Jihad Daneshghahi.

Nezamdoust, A. (2011). Children's literature in contemporary Arabic literature. Unpublished Master's Thesis, Ferdowsi University of Mashhad, Iran.

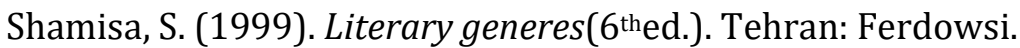


Taghipour, E. (2011). Humor in children's literature. Unpublished Master's Thesis, University of Guilan, Iran.

Tahouri, M. (2002). A drip of singing a piece of moonlight. Journal of Child and Youth Literature, 31, 187-189.

Yousef, A. (1970). Halgheh al-EnayehBelsaghefeh al-GhomiyehLeltefl. Cairo: al-Hei'at al-Mesriyh alA'me Le-ketab. (The Commission of Considering Child's National Culture).

Zanghaneh, S. (1994).Children's literature in the Arabic countries. Adabestan Magazine, 56, 15-17.

Zelt, A. (1994). Adab al-Tofoleh, OsolehvaMafahimeh. No place: No name. (Children's Literature, Its Principles and Methods). 